
History
Education
Research
Journal

\title{
Student responses to differing accounts of a controversial historical issue: 15-year-old Greek students consider the removal of children in the Greek Civil War
}

\author{
Vasileios Kosmas* - Democritus University of Thrace, Greece
}

\begin{abstract}
In recent decades, controversial issues have come to the forefront of history teaching. So far, they have been utilized in three ways: (1) to manage tensions in divided societies; (2) to instil humanitarian values into students; and (3) to enhance the teaching of second-order historical concepts. This study is based on the findings of other relevant research, and underpins the use of controversial accounts in order to foster procedural concepts of history. It was conducted in three middle schools of the Xanthi Prefecture, northern Greece, in 2017 and 2018. The subjects were 94 15 -year-old students, and the design was experimental. After being taught two versions of the Greek Civil War, a traditional and an experimental one, students expressed their opinions about three pairs of different historical accounts of a controversial issue: the removal of children during the war. A pilot study consisted of role-playing activities involving historical competences. After qualitative and quantitative analysis, a variety of ideas emerged about the differences in the accounts, the reasons for their differentiation, and the epistemological status of history. The findings show that: (1) students' comprehension depended on the level of difficulty of the accounts; and (2) the experimental groups modified their ideas about the different accounts and history to some degree. In conclusion, a structured, disciplinary approach to controversial historical issues, focused on role-playing activities, could contribute to a refinement of students' epistemological notions.
\end{abstract}

Keywords: controversial issues; different accounts; experimental design; Greek Civil War; role-playing activities

\section{Introduction}

\section{Controversial issues in education}

In recent decades, educators have placed particular emphasis on the use of controversial issues in history education. Controversial issues were utilized in the USA from the beginning of the twentieth century for the purpose of developing citizenship. American educators dealt with basic aspects of controversial issues, such as the teachers' and students' stance or the school's policy (Adams et al., 1948; Krey, 1933; Story, 1952). Since the 1960s, British educators have also engaged in the study of controversial issues. In particular, innovative projects such as the Humanities Curriculum Project (Stenhouse, 1971) imported controversial issues more efficiently into classrooms and systematized their study. After 1990, the discourse on controversial issues crossed the boundaries 
of the Anglo-Saxon world and expanded to France. French educators introduced the term 'questions vives', which means vibrant, intense issues (Chevallard, 1997). Since 2000, the study of controversial issues has spread to many countries, such as states of Eastern Europe (Misco, 2007), Asia (Baildon et al., 2014) and Africa (Asimeng-Boahene, 2007). The treatment of controversial issues has recently become a concern even for Greek scholarship. The main reference works focus on teaching contentious issues in history lessons (Kokkinos and Mavroskoufis, 2015; Kokkinos et al., 2010).

Controversial issues are related to disagreements, opposing views and different values. Their definition varies depending on the meaning that each educator attaches to the word (Bailey, 1975; Dearden, 1981; Hand, 2008). So far, educators have put forward many arguments for their use in education. They consider them suitable for students to expand their cognitive horizons and become familiar with the contradictory and ambiguous nature of knowledge. They also provide students with the opportunity to develop critical, social and emotional skills, and ultimately to become aware and well-informed citizens (Hahn, 1994; Hess, 2009; McLaughlin, 2003). The introduction of controversial issues into school practice encounters many obstacles. Students' and teachers' biases, various barriers within an educational system, and stereotyped perceptions of society could restrict the teaching of a controversial issue. Finally, teachers handle these issues not only in history classes but also in teaching a variety of subjects, including social studies and sciences (Stradling et al., 1984; Wellington, 1986).

\section{Controversial issues in history}

In history teaching, educators utilize controversial issues for three, usually interconnected, purposes. First, they aim to reduce tension in divided societies to a manageable level. The teaching of the conflict of the two rival communities in Northern Ireland is a typical example (Barton and McCully, 2007). Second, they aim to instil universal, humanitarian values in students. This is often the primary goal of the teaching of the Holocaust (Schweber, 2004) or the civil rights movement in the USA (Saye and Brush, 1999). Third, they seek to familiarize students with the multidimensional approach to historical reality and the complex role of the historian. Teaching about the use of the atomic bomb in the Second World War (Doppen, 2000), aspects of the founding of the USA (VanSledright, 2002) or the case of Operation Coldstore in Singapore (Baildon et al., 2018) fall into this category. This study focuses on the third aim: to familiarize students with a multidimensional approach to a historical event, and to explore how students might perceive history in a multi-perspectival way, through conflicting or different accounts of the same issue.

\section{The research}

\section{Research questions}

The main question of the research was whether the teaching of a controversial issue using a certain method, namely role-playing activities in connection with historical skills, fosters students' historical thinking. In particular, we investigated: (1) whether the students could understand the intricate nature of a controversial historical issue and approach it in a critical, multidimensional way; and (2) if they could realize that any historical narrative is not a solid reflection of an objective past but a particular view of it, dependent upon the narrator's perception. 


\section{Empirical framework}

This study was based on a vast body of literature published since the early 1990s. Specifically, researchers have explored how students approach different narratives of a historical issue. We could classify them into two broad categories.

First, there is research concerning ideas about the accounts of different historians. The research was mainly descriptive, and addressed to primary, secondary and higher education students, teachers and prospective teachers. The researchers presented different accounts by historians to the subjects, and invited them to explain the variation. The findings revealed a series of levels of historical thinking, partly related to the subjects' ages. The Concepts of History and Teaching Approaches (CHATA) project in Britain proposed a six-stage progression model of 7-year-old to 14-year-old students' ideas (Lee, 1998, 2001, 2004; Lee and Shemilt, 2004). Some students, especially the younger ones, did not realize that the accounts were different. Others argued that accounts differ because we cannot witness the past. At Levels 1 and 2, therefore, accounts are seen simply as stories, without epistemological status. At Level 3, students claimed that historians have deficient knowledge, gaps in their information or access to different sources. Others maintained that accounts differ because historians deliberately distort reality for ulterior motives. Thus, at Levels 3 and 4, students perceived history as a set of objective facts, which could be misrepresented because of archival gaps or biases. For Level 5 and Level 6 students, accounts are considered to be constructions, rather than copies of the past. Some argued that differences exist because each historian has his or her own legitimate point of view. Others attributed the variation of accounts to different questions and different criteria used by historians.

The findings of CHATA were confirmed in slightly different ways by research in diverse settings, such as Portugal (Barca, 2005; Gago, 2005), Taiwan (Hsiao, 2005), South Korea (Park, 2008), Singapore (Afandi, 2012; Afandi and Baildon, 2015), Germany (Martens, 2015) and the UK (Chapman, 2009; Chapman and Goldsmith, 2015). Similar research in the USA has also produced models consistent with the findings of these studies. In small-scale research, VanSledright and Afflerbach (2005) proposed a threelevel classification of primary students' ideas: (1) the realist position, which treats the past as fixed or inaccessible; (2) the naive realist position, which attaches significance to the degree of bias of an author; and (3) the criterial position, which emphasizes the choice of a point of view according to criteria. The reliability of this model was tested in primary school teachers (Maggioni et al., 2009).

The second category of research explores how students in secondary and higher education manage conflicting primary and secondary sources. One of the fundamental studies was that of Wineburg (1991a, 1991b), who gave different written and pictorial sources about a battle of the American Revolution to professional historians and high school students in order to compare how the two groups would handle them. He found that the students had not used three skills ('heuristics') that belong to the methodological toolkit of historians: (1) focusing on the narrator of the sources ('sourcing'); (2) associating evidences of the sources ('corroborating'); and (3) placing the sources in the space-time context of their production ('contextualizing').

In addition, research in the USA found that the use of certain teaching methods and tools could be quite useful. Many of those were experimental. Wiley and Voss (1996) argue that the combination of reading different sources and writing argumentative essays yields the most historian-like behaviour in undergraduates. Another study showed that reading multiple sources about a controversial historical issue in a structured, digital environment influenced college students' ability to reason with and about documentary evidence (Rouet et al., 1996). Following that research, 
Britt and Aglinskas (2002) developed the 'Sourcer's Apprentice', a computer-based tutorial and practice environment, and applied it to high school and college students. Using the digital resource, the experimental groups wrote essays about controversial topics that were more integrated, cited more sources and referenced more information than those of the comparison groups. Furthermore, systematized, disciplinary, literacy instruction with the use of conflicting accounts helped college students to modify their epistemological beliefs about history (Hynd et al., 2004). The benefits of scaffolded historical learning were also evident in other experimental studies. During the teaching of controversial aspects of modern American history, instruction in historical reasoning strategy assisted middle and high school students in producing argumentative essays about controversial issues that were longer, and more accurate, persuasive and elaborated than those of their peers in control groups (De La Paz and Felton, 2010; De La Paz et al., 2014; De La Paz et al., 2017).

\section{Sample and tools}

We conducted the empirical part of the research in three middle schools of the Xanthi Prefecture, northern Greece (see Figure 1), in the spring of 2017 and 2018. We used a convenience, disproportional sampling. The schools belonged to three different areas of the prefecture, a rural, a semi-urban and an urban area. The sample consisted of 94 15-year-old students of the third grade $(\mathrm{N}=94)$. In order to ensure respondent anonymity, we gave each student a code, which consisted of the year of the survey, the initials of the school and the class, and a serial number. Three main tools were used to record students' ideas: (1) recordings of the teaching; (2) written tests before and after teaching; and (3) recorded interviews with selected participants. This paper presents some of the findings of the written tests.

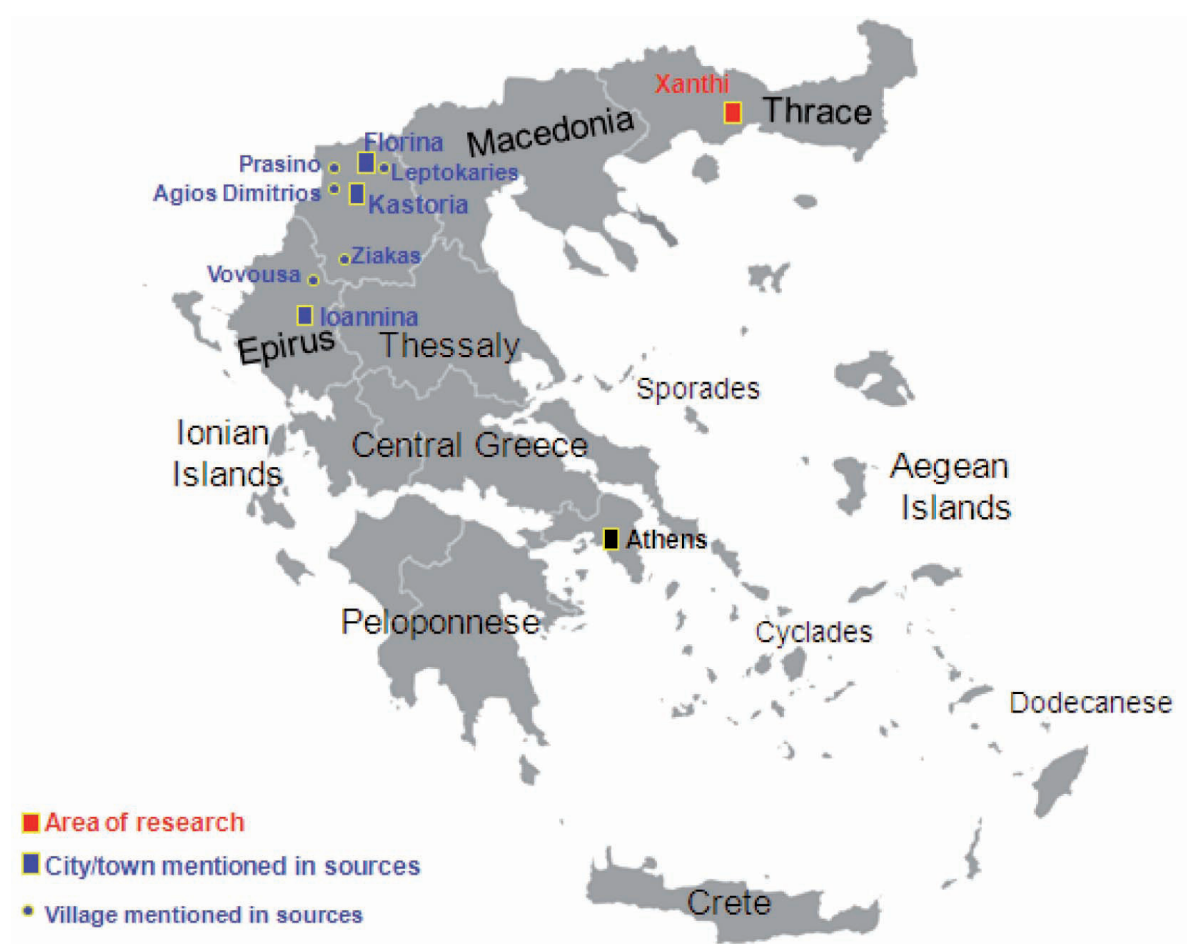

Figure 1: Map of Greece showing cities, towns and villages mentioned in the sources used in the tests and related to the removal of children during the Greek Civil War (see Appendices 1 and 2)

Source: Author's drawing 


\section{Thematic field}

The historical issue we chose comes from the context of the Greek Civil War of the 1940s. This is one of the most controversial periods in the history of modern Greece, and it has been much discussed in the academic community over the past decades (Kalyvas and Marantzidis, 2015; Voglis, 2014). Greek students learn about the period in the third grade of middle school. In particular, we focused on a controversial aspect of the war, the removal of children from northern Greece. Specifically, two rival groups, the left-wing rebels and the centre-right government, conducted massive relocations of children to Eastern European countries and special camps in Greece, called paidopoleis ('childtowns') (Bærentzen, 1987; Danforth and Van Boeschoten, 2012). The matter in dispute is whether both sides abducted the children for military and political purposes, or saved them from the suffering of the war with parental consent. There are three types of account in the scholarship concerning this question: (1) the accounts of simple, everyday people who experienced the removal; (2) the accounts of politicians and military officers who represented the conflicting parties; and (3) the accounts of researchers.

\section{Research design}

In order to explore students' ideas about the different historical accounts, we designed a quasi-experimental intervention (Cohen et al., 2007). First, we divided the classes of each school into two groups, the experimental and the control group. There were three experimental groups and two control groups altogether, because one of the three schools had only one class in the third grade. A traditional one-hour lesson on the Greek Civil War allowed the students to acquaint themselves with the historical context of the issue. In particular, they learned about the factors that contributed to the conflict, the opposing groups, the leading figures and their international supporters.

Subsequently, the students of both the experimental and the control groups took a pre-test concerning the removal of children by the left-wing insurgents of the Democratic Army and the Communist Party of Greece. That test included tools that researchers used in the aforementioned descriptive studies. Specifically, there were three pairs of narratives: (1) of everyday people; (2) of politicians and military officers, members of the opposing sides; and (3) of scholars (see Appendix 1). The six sources were concise and similar in length; their readability differed because they represented the speech of different groups. They were also adapted according to the level of the readers and the needs of the test (Wineburg and Martin, 2009). The students had to state whether there were differences in each pair of sources, how the narratives differed, and why there were different narratives of the same historical issue. The aim was to explore how Greek students think about the different narratives and, consequently, the nature of history. Furthermore, there were Likert-type items that concerned two diametrically opposite views of history. The first statement was a one-dimensional and positivist claim ('In any historical issue there is only one sensible, correct and credible point of view'). The second one was an extreme relativistic claim ('In any historical issue every point of view is sensible, correct and credible'). Our intention was to capture signs of students' epistemological perceptions of history.

After the pre-test, only the students in experimental groups attended three-stage teaching about the controversial issue of the removal of children. The comparison groups, in contrast, continued the ordinary history lessons, without focusing on the contested matter or being exposed to the same teaching method. At each stage of the experimental intervention, the students approached the three levels of different 
accounts, the micro-historical, the political and military, and the historiographical one, respectively. The concept of multi-perspectivity - the various perspectives of a historical phenomenon (Stradling, 2003) - was at the core of the teaching. In addition, roleplaying activities and the notion of historical empathy played a leading role. We drew these techniques, unaltered and unmodified, from guides on tackling controversial issues (CCEA, 2015; Emerson et al., 2012). We also based the three-stage teaching on the findings of Wineburg's (1991a, 1991b) research in order to familiarize the students with each of the three heuristics that historians use when they handle their material. Figure 2 presents the characteristics of each stage.

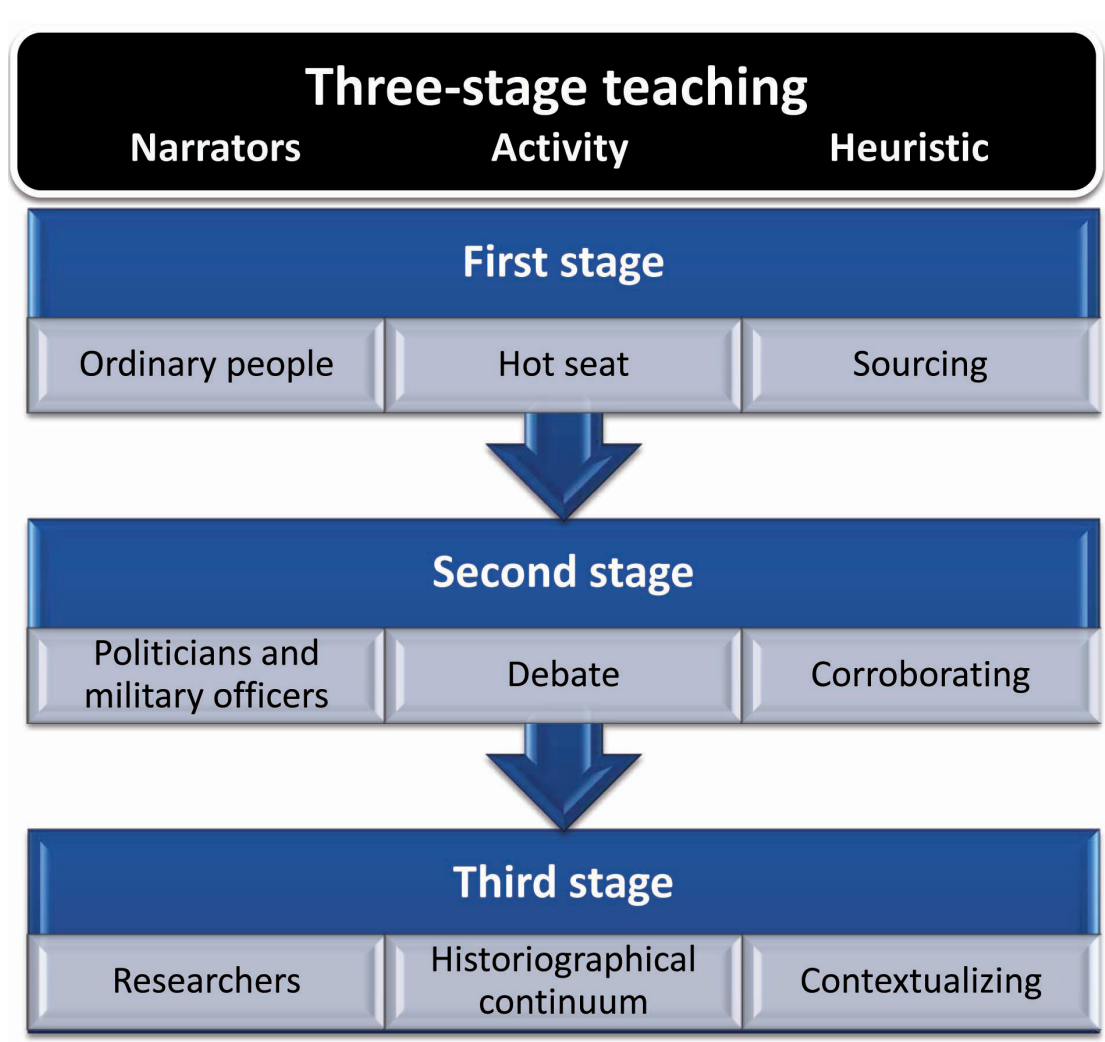

Figure 2: The stages of the teaching and their characteristics

During the first stage, the students approached the micro-historical level of the issue and read the testimonies of unknown persons. The sources represented a variety of narratives from people such as parents, children and children's escorts, who came from various regions of northern Greece. The aim of this stage was to familiarize students with the heuristic of sourcing, namely focusing on narrators, their qualities and possible biases. After studying a document, each student sat on a chair in front of a semicircular seating arrangement, tried to impersonate the narrator of the source, and shared the experience of the removal. At the same time, the researcher interrogated the student to facilitate the narrative flow and highlight the diversity of testimonies. Finally, there was a plenary discussion about the differences in the narratives and the possible reasons for these differences.

The second stage concerned the political and military level, and had two phases. During the first phase, some students studied relevant documents and participated in a fictional debate that supposedly took place at the UN headquarters in winter 1948. In particular, two students took the role of the insurgents' representatives and two others 
were the delegates of the official Greek government. The researcher and a student played the role of the UN officials, coordinated the debate and finally announced the findings of the actual UN report on the removal. Each side attempted to express its views and support them with authentic documentary and audiovisual evidence. The rest of the students participated in the second phase as researchers in order to familiarize themselves with the heuristic of corroborating. Specifically, they compared the allegations they had already heard with the evidence of written and visual sources, and evaluated the arguments of both sides.

In the third stage, the students dealt with the issue at the level of historiography, and compared the accounts of five well-known scholars from different times. Five students took the role of the historians and read their views about the removal in the plenary. One of the aims of this stage was to familiarize students with the heuristic of contextualizing. The historians' narratives concerning the perspectives of the right and the left on the issue in different time periods were extremely helpful. After each student/historian had announced his or her view, the rest of the students discussed it, and suggested that he or she sit on a chair in a row of five seats, which represented a continuum of historical views. One end of the row corresponded to military reasons for the removal, while the other end corresponded to humanitarian reasons. The students placed the historians who had mentioned both military and humanitarian reasons close to the middle of the row, depending on the importance they had attached to each factor. In the end, there was a plenary discussion about the possible reasons for the differentiation of narratives even in academic circles.

After the intervention, the students of both groups took a post-test in the same format as the previous one. However, the different narratives concerned the reverse angle of the same issue, namely the removal of children by the centre-right Greek government, the National Army of Greece, and a welfare organization of Queen Frederica, called Eranos ('The Fund') (see Appendix 2). The aim was to track any changes in the way the students perceived the different narratives and the nature of history.

\section{Findings}

\section{Qualitative analysis}

Data analysis was both qualitative and quantitative. Regarding the qualitative analysis, we used the inductive coding of grounded theory (Glaser and Strauss, 1967). In particular, we coded each student's response and, after coding of several responses, categories with common features emerged. After entering new data, we modified or enriched the categories and created new, larger ones.

Concerning the differences of the accounts, the analysis revealed four main categories of responses. First, some students found no difference in certain pairs of accounts (Category A). There were also students who reported unfounded differences (Category B): they copied passages from the sources, combined irrelevant information or gave unspecific answers, as the following excerpts show:

The first source speaks of the National Army planes and the second source reports that the Communists called those who had little children to the village square. (2017-GG-G1-01, pre-test)

I believe the two texts are not related to each other. (2017-5G-G2-05, pre-test) 
A few students mentioned differences that existed but were of minor importance (Category C). In the excerpts below the students focused on differences in the vocabulary and rhetorical style of sources:

In the fifth source Queen Frederica founded an organization for children, called Eranos, while in the sixth source it is mentioned that Frederica created foundations for children. (2018-GA-G1-05, post-test)

The first source explains the situation in third person. The second one narrates a child's story in first person. (2017-5G-G2-20, pre-test)

Finally, there were answers that referred to substantial differences (Category D). The differences were related to the existence of the factor of violence during the removal, or the way that the narrators presented the opponents and their motives. These are two indicative excerpts:

In the first source they took the children violently and transported them to the town of Florina, while in the second source the children willingly went, without being forced by anyone. (2017-5G-G4-01, post-test)

The fifth source says that they wanted to save the children from starvation and protect them, while the other source says that they lacked soldiers and took children and women to fight. (2018-GA-G1-16, pre-test)

Regarding the explanations for the differences, we also formed four main categories. First, some students did not give any explanation for the variation between pairs of sources (Category A). Most of these students had not detected any difference in response to the previous question. Second, several students gave unfounded explanations (Category B): either they reproduced extracts from the texts, rephrased differences they had already written about, or answered a different question. In the latter case, some apparently misunderstood the question and mentioned the possible causes of the removal and not the plausible reasons for the variation in the narratives. For example, two of the students answered:

The first source says that the children were taken violently, while the other one says that they were leaving of their own free will. (2018-GA-G1-16, post-test)

They took the children to protect them. (2017-GG-G2-07, pre-test)

Some students interpreted the differences in terms of factual aspects (Category C). They ascribed them either to the different behaviour of historical actors, such as parents and soldiers, or to the different space-time conditions. These are typical answers of this kind:

In the first source the soldiers may not have been strict, but in the second one they were strict and took the child without asking his mother. (2017GG-G1-04, pre-test)

The narratives may have come from different villages and the Communists took the children in different ways. (2017-GG-G2-09, pre-test)

The last category (Category D) is related to narrator-based explanations, and includes several subcategories. Some students attributed the differences to the lies of one or both narrators, while others claimed that they were due to the different perceptions or perspectives of narrators. Many students referred to possible ideological biases or 
interests, even in the case of historians, or referred to real characteristics of narrators to explain the differences. These are examples of narrator-based explanations:

The third source comes from an important person who wants to present only the positive side and possibly lies. The fourth source is a complaint that probably exposes the real situation. (2017-5G-G2-07, pre-test)

Because each writer had a different perception. (2018-GA-G1-01, post-test)

Because Polymeris Voglis [a historian] may have been a communist, while Nikos Marantzidis [a political scientist] was not. (2018-GA-G1-02, pre-test)

In the third source the narrator is left wing, therefore underestimates the queen. In the fourth source Queen Frederica speaks, so she defends her plans. (2018-GA-G1-07, post-test)

We can make some useful observations about the classification of the differences and their explanations. Concerning the differences, there seems to be a scaling from a lower to a higher level. In particular, finding a substantial difference is preferable to finding an insubstantial one or just reproducing an extract. However, as far as explanations are concerned, scaling is relative and depends on the pair of sources and their particularities. An explanation for the different narratives of two ordinary people based on factual aspects is not, by definition, inferior to an explanation based on their ideology. The variation of their testimonies may be due not only to their bias, but also to different circumstances in their villages. On the other hand, an explanation based on factual considerations has less interpretative power in the case of the different accounts of two historians.

Besides that, some students gave hybrid answers that contained elements of two categories or subcategories of differences and their explanations. These are two typical examples:

In the first source they did not push or threaten the parents to send their children off as they did in the second source, where they grabbed a child from a village street. In the first source they did not take the children out of their parents' arms. Also, in the first source the order was to remove all children, while in the second source only the young ones. (2017-5GG2-11, pre-test)

The differences are due to the different way people think and their interests. (2017-5G-G4-12, post-test)

In the first case, the student mentioned first and foremost a substantive difference in the first pair of narratives, the use of violence (Category D). However, at the end of her answer, she focused on a slight difference in the verbal formulation of the two sources (Category C). In the second example, the student combined two different types of narrator-based explanation (two subcategories of Category D). She quoted the perception of the narrators as well as their interests in order to interpret the differentiation of the narratives.

Moreover, the answers of several students varied according to the pair of sources. This student is indicative of the variation:

In the first source perhaps the parents gave soldiers permission to take their child for safety reasons, while the parents of the second source did 
not want to leave their children because they thought it would be better. (2017-5G-G2-04, pre-test, Sources 1 and 2)

In the third source citizens send requests to public organizations and ask for help. In the fourth source the children were removed without the involvement of parents or organizations. (2017-5G-G2-04, pre-test, Sources 3 and 4)

The writers may be influenced by their origins, because the second source was written by a person from Macedonia. I believe that a historian has a point, if he is objective. This is their job. (2017-5G-G2-04, pre-test, Sources 5 and 6 )

In particular, this student gave a factual explanation for the first pair, since she ascribed the differences to the different behaviours of the parents (Category C). For the second pair, she just restated the differences of the narratives, without giving any explanation for them (Category B). Finally, she gave a narrator-based explanation for the third pair (Category D). Specifically, she confused the affiliation of a researcher with his origin, and believed that it had influenced his point of view. At the end of her answer, she added an interesting remark about the desired objectivity of historians. Consequently, the field of students' historical ideas seems extremely complex, and it is difficult to create stable models of them.

\section{Quantitative analysis}

The data from written tests were also subjected to a quantitative analysis. First, the readability level of the accounts affected the students' comprehension to a significant extent. The frequencies of the categories of differences among the three pairs of sources differed significantly in the pre-test $\left(X^{2}(6)=17.2, p=.009\right)$ as well as in the post-test $\left(x^{2}(6)=48, p<.001\right)$. On the one hand, the students found more substantial differences in the first pair of sources, which was the most comprehensible. This is due to the simple way in which the ordinary people expressed their thoughts. On the other hand, the students detected fewer substantial differences in the second and third pairs, which represented the complex and abstruse narratives of politicians and military officers, and researchers respectively.

Regarding the differences found by the experimental and control groups, there were no statistically significant discrepancies in the pre-test $\left(X^{2}(3)=4.39, p=.22\right)$. However, in the post-test, the students of the experimental groups found significantly more substantial differences than their peers in the control groups $\left(X^{2}(3)=28, p<.001\right)$. This is an indication that they had a firm grasp of the matter after the intervention. There was also a significant deviation concerning the explanations of differences. In the pre-test, both the experimental and the control groups construed the differences of the accounts in a similar way $\left(x^{2}(3)=.52, p=.91\right)$. In the post-test, the students of the experimental groups gave significantly more explanations based on factual aspects and the narrators compared to the students of the control groups, who did not drastically change the way they interpreted the variation $\left(X^{2}(3)=20.6, p<.001\right)$.

Finally, the findings of the Likert-type items were also revealing. Although most of the students of the experimental groups agreed more or less with the one-dimensional view of history at the beginning, there was a statistically significant shift towards a partial or complete disagreement after the intervention $(Z=3.96, p<.001)$. By contrast, the majority of the control group students were inclined to take the positivistic perspective in the pre-test as well as in the post-test $(Z=.81, p=.42)$. Regarding the extreme 
relativistic view of history, there were no significant differences, since the majority of the students of the experimental groups disagreed with this statement to a greater or lesser extent in both the pre-test and the post-test $(Z=.95, p=.34)$. The same results also emerged in the control groups $(Z=.95, p=.34)$.

\section{Discussion}

\section{Limitations and questions}

The findings of this study meet certain constraints in terms of both teaching and data analysis. Furthermore, several questions arise concerning the results. First, the Greek Civil War is without doubt a controversial issue. However, it is not a sensitive one for the sample in the research. The findings of a preliminary questionnaire showed that Greek students have poor knowledge of that period of history and the cultural trauma of the war was not passed on to this generation. To what extent would the findings be different if the students were emotionally attached to this issue, and had persistent, stereotypical ideas?

There are also important constraints concerning certain features of the intervention. The first is the limited duration of the teaching: long-term teaching of controversial issues might have induced more profound changes in the students' ideas. In addition, short-term changes in students' ideas do not necessarily imply long-term alteration of their understanding, which depends on various factors. Second, several questions arise concerning the teacher's role and the teaching methods. How did the teacher's fidelity to the intervention affect the final result? How did each stage and activity separately shape the students' ideas? Which factor was the most influential? Could the enriched notions be transferred to a different controversial issue? What would have been the results if the comparison groups had attended a different teaching of the same issue? Further research could shed light on some of these questions.

Concerning the data analysis, we cannot rule out the possible presence of the common effects of an experimental design. In addition, an important factor is the prism of the researcher who imposes his or her mental pattern during the collection and elaboration of the material. Third, we chose a combination of qualitative and quantitative analysis in order to exploit the advantages of both. The first leads to a thorough study of the variety of students' responses, while the second allows their statistical analysis. However, the transition from the qualitative to the quantitative analysis is always difficult, because some qualitative features are lost in the process of merging categories. Finally, the generalizability of the findings is limited to the sample population, and the conclusions are therefore tentative and provisional.

\section{Contribution and results}

This study enriches the expanding body of knowledge concerning students' ideas about different accounts and their use in history teaching. The findings cannot be fully comparable to those resulting from descriptive research, since the students expressed their ideas not only about the different accounts of historians - the purely disciplinary nature of history-but also about the different narratives of historical agents. Nevertheless, the study revealed a common general trend, for there were notions across all three pairs of sources that are consistent with the three-level model of the 'factual', 'multiple' and 'criterial' past (Afandi and Baildon, 2015; Lee, 2001). In other words, some students approached the accounts as copies of a fixed past, others acknowledged the past as complex and multifaceted, and several handled the narratives as reconstructions of 
past events. However, the students' ideas were not always clear-cut, as other studies have also shown (Afandi, 2012; Chapman, 2009). They shifted across a factual-multiplecriterial continuum according to the particularities of the sources. For instance, the testimonies of people from different villages incited some students to explain the variation in terms of a complex past, especially after the intervention that brought out the different local aspects of the removal. In this case, the notion of a multifaceted past has not a priori less interpretative power than that of a criterial past. Finally, concerning the different accounts of historians, it is worth noting that the majority of the narratorbased explanations referred to the narrator's alleged ideology or a vague personal viewpoint, which are reminiscent of Levels 4 and 5 of the CHATA model. Certainly, the danger of a relativistic perception of history looms in the latter case, since some students may assess the accounts regardless of the evidence that support them. In contrast, very few students explained the variation of historical accounts in terms of different criteria, and none of them in terms of different questions (Level 6).

Concerning the impact of the intervention, the findings of the study are also aligned with those of other experimental research, which highlights the importance of structured teaching, focused on disciplinary knowledge. Yet this study contributes a new perspective to instruction in disciplinary literacy. Regarding the research questions, a positive influence of certain teaching methods, such as role-playing activities, on students' epistemological beliefs was detected. The increase of the experimental groups' answers that referred to substantial differences indicates a better comprehension of the matter. Furthermore, the change in the way in which the experimental groups tended to interpret the variation of accounts shows that the intervention led some students to use elaborated ideas about a complex or constructed past, without completely abandoning their previous mental schemas or making rapid progress. In other words, the enhancement of their historical thinking reached certain limits. This positive trend was also detected in the answers of the experimental groups concerning the two opposite views of history. Several students approached the notion of multi-perspectivity, doubting the positivistic view of a single, proper history, yet the actual degree of their shift was unclear.

Finally, although the issue was not sensitive for the sample, interviews revealed that some students had a different kind of emotional connection with the issue. They showed a particular empathy to some extent, as some of the main historical agents were their peers at that time. Put differently, they displayed empathy as caring for people in history (Barton and Levstik, 2004).

\section{Implications and conclusion}

In conclusion, the research confirmed that the field of students' historical ideas about different historical accounts is complex. The features of the exploratory tools we use, such as the chosen topic and the sources, have an impact on students' ideas and, therefore, the models of historical thinking should have a degree of flexibility. In addition, student-centred teaching of controversial issues, which focuses not only on the transmission of information but also on the process of constructing historical knowledge, could have a beneficial effect compared with traditional instruction.

This assertion is of particular importance in regard to the Greek context of history teaching, where the narratives of the teacher and the textbook play a dominant role. The findings of the preliminary questionnaire and interviews showed that many students were accustomed to teaching based upon the passive learning of declarative knowledge and a picture of history as a credible copy of the past. This stresses the need for a better-structured national curriculum, which will place greater emphasis 
on teaching the discipline of history, and for systematic teacher training in fostering procedural knowledge, among other things. Under certain conditions, the teaching of controversial issues, based on the discipline of history, could provide some students with a stimulus for refining their way of thinking about history. It could help students to consider multiple perspectives and realize that historical narratives are neither sums of information ready to use nor accurate depictions of a fixed past.

\section{Notes on the contributor}

Vasileios Kosmas is a secondary school teacher and $\mathrm{PhD}$ candidate at the Democritus University of Thrace, Department of Primary Education. He received a master's degree in Byzantine archaeology from the University of loannina. His research interests include history teaching, historical thinking and controversial issues. He recently participated in the Greek edition of the project Shared Histories for a Europe Without Dividing Lines.

\section{Appendix 1}

Pre-test: Six different accounts of the removal of children by the Democratic Army and the Communist Party of Greece

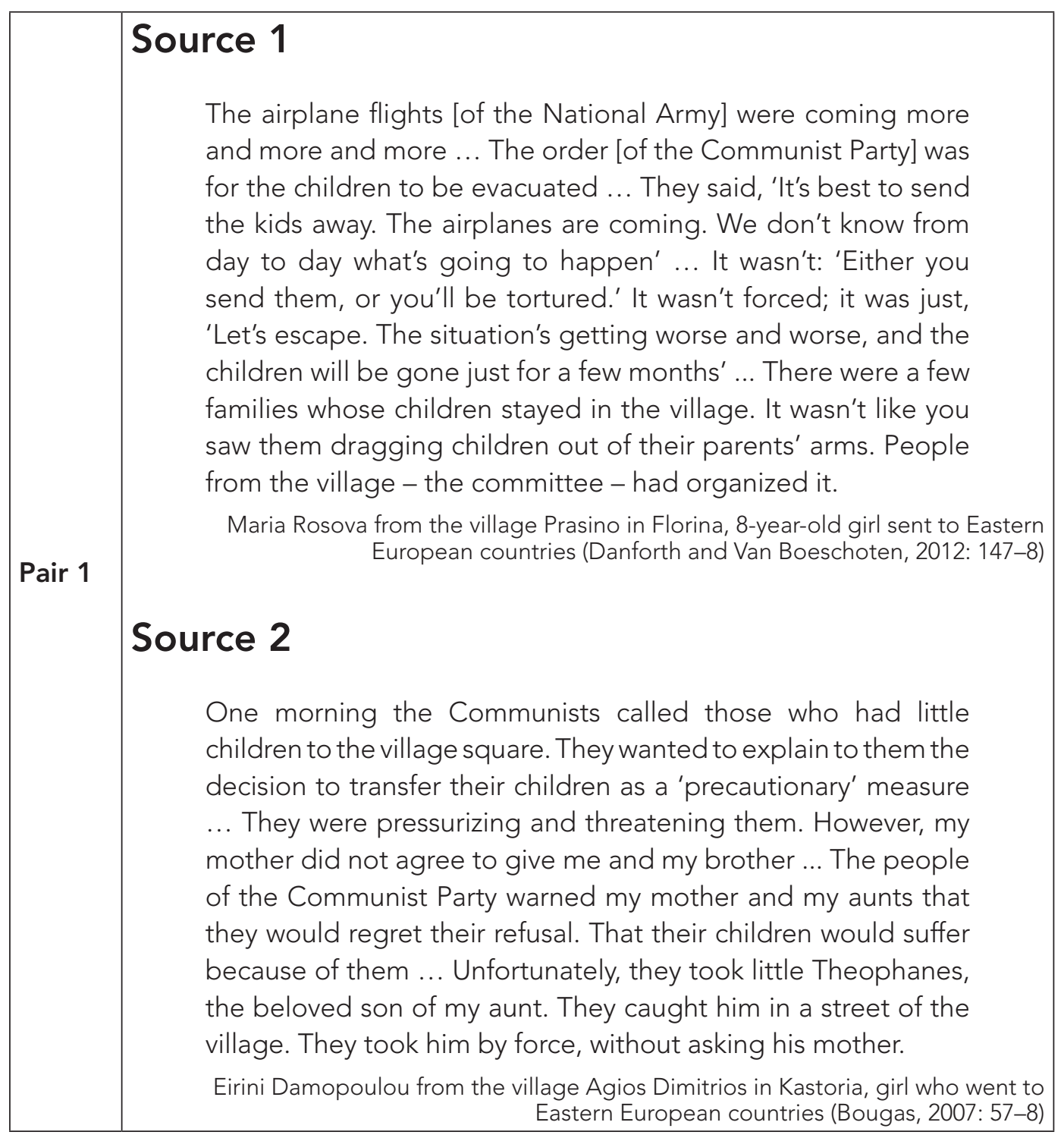




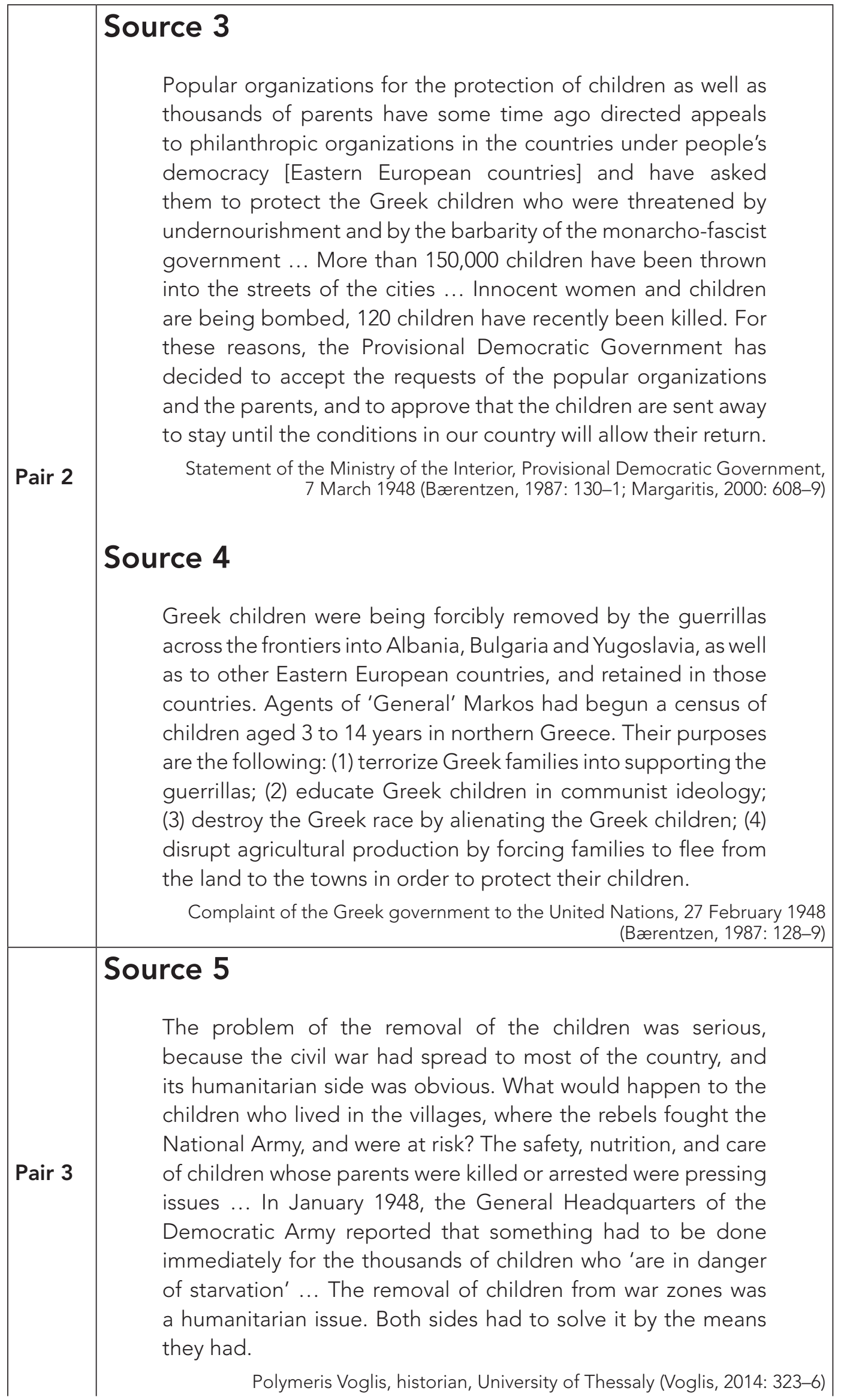




\section{Source 6}

The decision of the removal of the children was based on military, not humanitarian grounds. The Democratic Army had a very serious problem finding soldiers. Markos Vafeiadis wrote that in 1947 'those who willingly joined the Democratic Army were not even 10\%'. The rebels did not find men and adolescents in the villages to recruit and forcibly took even the women and teenage girls. As time passed, the number of female guerrillas grew ... The Democratic Army decided to move the children so that their parents, and especially mothers, could fight ... Thus, having their children in the Eastern European countries, parents could not leave the areas controlled by the rebels.

Nikos Marantzidis, political scientist, University of Macedonia (Marantzidis, 2008)

\section{Appendix 2}

Post-test: Six different accounts of the removal of children by the National Army, Greek government and Queen Frederica's organization

\begin{tabular}{|l|l|}
\hline Source 1 \\
I was in the house when they [the soldiers of the National Army] \\
came to take me. They spoke to my parents: 'We're evacuating \\
the children. It's for their own good. They'll be going to school; \\
they'll be safe.' But the fact is, we were taken by force. My \\
parents couldn't understand it. They refused, both of them ... \\
The soldiers were armed; they hit my parents and said, 'Stay \\
back!' My poor mother! She pushed the soldiers away ... I was \\
afraid to do anything because they could shoot you right there \\
on the spot ... I didn't want my parents to be in danger. If I'd said, \\
'I'm not gonna go', I figured my parents would be shot. And so \\
they loaded us on the trucks and took us to Florina [town]. \\
Traian Dimitriou from the village Leptokaries in Florina, 14-year-old boy sent to \\
Queen's camp (Danforth and Van Boeschoten, 2012: 169) \\
Source 2 \\
All the children in Vovousa [village] wanted to go to loannina \\
[city]. For us loannina was a dream ... On my way, I saw my \\
aunt's two children dressed up and ready to go to loannina \\
$\ldots$. I said to my mother: 'Thanasis and Marigoula are going to \\
loannina with the army.' My mother went and asked my aunt, to \\
make sure I was telling the truth. Then she dressed my brother \\
and me up, and in the blink of an eye we were off with the army \\
to loannina. My father was still in Ziakas [village]. If he'd been at
\end{tabular}




\begin{tabular}{|c|}
\hline $\begin{array}{l}\text { home, he never would have let us go. No one took us by force; } \\
\text { we wanted to go. That's important; I want to emphasize that. } \\
\text { Kostas Dimou from the village Vovousa in loannina, 8-year-old boy sent to } \\
\text { Queen's camp (Danforth and Van Boeschoten, 2012: 177-8) }\end{array}$ \\
\hline rce 3 \\
\hline $\begin{array}{l}\text { The government of Athens described the right and humanitarian } \\
\text { act of the Democratic Army as 'child abduction', but the real } \\
\text { abduction was made by the state of Athens. That's because the } \\
\text { children of the rebels, who fell into its hands with terror and lies, } \\
\text { had been incarcerated in detention camps, in the so-called Queen } \\
\text { Frederica's schools. There, they were really taught that their parents } \\
\text { were traitors and that they should betray them to the police! ... } \\
\text { What happened to the rebels' children who were confined there? } \\
\text { How many of those are living? How many were educated? What } \\
\text { kind of jobs do they have? No official data has ever been provided. } \\
\text { The silence of our opponents is very suspicious! }\end{array}$ \\
\hline $\begin{array}{r}\text { Vasilis Bartziotas, member of the Communist Party and political commissar of } \\
\text { the Democratic Army (Bartziotas, 1981: 128, 132) }\end{array}$ \\
\hline
\end{tabular}

\section{Source 4}

The main project was to save our children in the northern provinces from being carried across the borders and from being educated as enemies of the country ... Their parents were only too glad to give them to us so as to save them ... Within a few months, 58 children's homes were established. We housed, fed and clothed 25,000 children. We educated them, taught them a trade and, when the countryside was safe again, they were sent back to their family homes ... The Queen's Ladies [women of the Athens elite] left their safe and comfortable homes, to save our children ... They rode for hours on mules, disregarding the dangers of war, to find our children, before the communists did.

Queen Frederica (Queen Frederica of the Hellenes, 1971: 134-5, 137)

\section{Source 5}

One of the main figures of 'children's salvation' was Queen Frederica ... On July 10, 1947 she created an organization, called Eranos [The Fund] ... As quoted in the archives of Eranos, the queen wanted to turn her attention to children, 'the future of the nation' ... Eranos was created to make the palace's position stronger in political conflicts and reinforce the queen's position in politics. This was because the anti-royalists accused her of being in the Hitler Youth. Also, many royalists did not like her because she was of German descent and a dynamic woman ... In the Greek Civil War, the issue of the removal of children was not just humanitarian but profoundly political.

Tasoula Vervenioti, historian, teacher in middle and higher education (Vervenioti, 2005: 103, 105, 123) 


\section{Source 6}

In order for the Communist Party not to take advantage of the problems of civilians, Queen Frederica tried to establish foundations across the country, in which about 25,000 children were hosted during the war ... As the queen mentioned in her memoirs, 58 foundations for children were created 'to get to them before the communists did'... Most of them were children of rebels and generally of people from war zones. The Queen's goal was both military and humanitarian. On the one hand, the Communist Party could not send children to the Eastern European countries. On the other hand, she took care of the children who suffered from the war.

Stathis Kalyvas and Nikos Marantzidis, political scientists, Yale University and University of Macedonia respectively (Kalyvas and Marantzidis, 2015: 444, 449)

\section{References}

Adams, R., Rodgers, M., Olney, A.F. and Smelser, J.N. (1948) 'Rules for controversial issues'. The Clearing House, 22 (7), 412.

Afandi, S.M. (2012) 'Conceptions about the Nature of Accounts in History: An exploratory study of students' ideas and teachers' assumptions about students' understandings in Singapore'. Unpublished PhD thesis, Institute of Education, University of London.

Afandi, S. and Baildon, M. (2015) 'Anxieties over Singapore students' conceptions about history and the past'. Humanities and Social Studies Education Online, 4 (2), 36-47.

Asimeng-Boahene, L. (2007) 'Creating strategies to deal with problems of teaching controversial issues in social studies education in African schools'. Intercultural Education, 18 (3), 231-42.

Bærentzen, L. (1987) 'The "Paidomazoma" and the Queen's Camps'. In Bærentzen, L., latrides, J.O. and Smith, O.L. (eds) Studies in the History of the Greek Civil War, 1945-1949. Copenhagen: Museum Tusculanum Press, 127-58

Baildon, M., Afandi, S., Bott, S. and Rajah, C. (2018) 'Guiding students in Singapore to investigate historical controversy using a disciplinary approach'. History Education Research Journal, 15 (2), 308-27.

Baildon, M., Seng, L.K., Lim, I.M., Inanç, G. and Jaffar, J. (eds) (2014) Controversial History Education in Asian Contexts. London: Routledge.

Bailey, C. (1975) 'Neutrality and rationality in teaching'. In Bridges, D. and Scrimshaw, P. (eds) Values and Authority in Schools. London: Hodder and Stoughton, 121-39.

Barca, I. (2005) '“Till new facts are discovered": Students' ideas about objectivity in history'. In Ashby, R., Gordon, P. and Lee, P. (eds) Understanding History: Recent research in history education. London: RoutledgeFalmer, 62-76.

Barton, K.C. and Levstik, L.S. (2004) Teaching History for the Common Good. Mahwah, NJ: Lawrence Erlbaum Associates.

Barton, K. and McCully, A. (2007) 'Teaching controversial issues... where controversial issues really matter'. Teaching History, 127, 13-19.

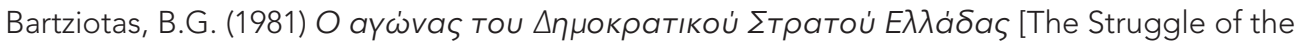
Democratic Army of Greece]. Athens: Sygxroni Epoxi.

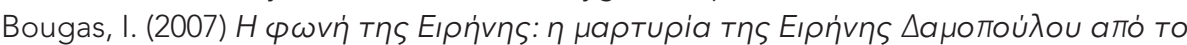

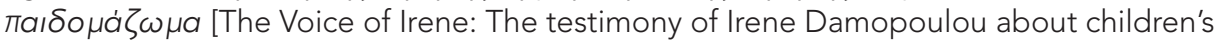
abduction]. Thessaloniki: Erodios.

Britt, M.A. and Aglinskas, C. (2002) 'Improving students' ability to identify and use source information'. Cognition and Instruction, 20 (4), 485-522.

CCEA (Council for the Curriculum, Examinations and Assessment) (2015) Teaching Controversial Issues at Key Stage 3. Belfast: Council for the Curriculum, Examinations and Assessment. Online. https://tinyurl.com/y2um3qpd (accessed 11 July 2019). 
Chapman, A.J. (2009) 'Towards an Interpretations Heuristic: A case study exploration of 16-19 year old students' ideas about explaining variations in historical accounts'. Unpublished PhD thesis, Institute of Education, University of London.

Chapman, A. and Goldsmith, E. (2015) '"Dialogue between the source and the historian's view occurs": Mapping change in student thinking about historical accounts in expert and peer online discussion'. In Chapman, A. and Wilschut, A. (eds) Joined-Up History: New directions in history education research. Charlotte, NC: Information Age Publishing, 183-210.

Chevallard, Y. (1997) 'Questions vives, savoirs moribonds: Le problème curriculaire aujourd'hui'. Paper presented at the Colloque Défendre et transformer l'école pour tous, Marseille, 3-5 October 1997. Online. https://tinyurl.com/yxlygdqc (accessed 11 July 2019).

Cohen, L., Manion, L. and Morrison, K. (2007) Research Methods in Education. 6th ed. London: Routledge.

Danforth, L.M. and Van Boeschoten, R. (2012) Children of the Greek Civil War: Refugees and the politics of memory. Chicago: University of Chicago Press.

Dearden, R.F. (1981) 'Controversial issues and the curriculum'. Journal of Curriculum Studies, 13 (1), 37-44.

De La Paz, S. and Felton, M.K. (2010) 'Reading and writing from multiple source documents in history: Effects of strategy instruction with low to average high school writers'. Contemporary Educational Psychology, 35 (3), 174-92.

De La Paz, S., Felton, M., Monte-Sano, C., Croninger, R., Jackson, C., Deogracias, J.S. and Hoffman, B.P. (2014) 'Developing historical reading and writing with adolescent readers: Effects on student learning'. Theory and Research in Social Education, 42 (2), 228-74.

De La Paz, S., Monte-Sano, C., Felton, M., Croninger, R., Jackson, C. and Piantedosi, K.W. (2017) 'A historical writing apprenticeship for adolescents: Integrating disciplinary learning with cognitive strategies'. Reading Research Quarterly, 52 (1), 31-52.

Doppen, F.H. (2000) 'Teaching and learning multiple perspectives: The atomic bomb'. The Social Studies, 91 (4), 159-69.

Emerson, L., Gannon, M., Harrison, C., Lewis, V. and Poynor, A.-M. (2012) Tackling Controversial Issues in the Citizenship Classroom: A resource for citizenship education. Dublin: CDVEC Curriculum Development Unit.

Gago, M. (2005) 'Children's understanding of historical narrative in Portugal'. In Ashby, R., Gordon, P. and Lee, P. (eds) Understanding History: Recent research in history education. London: RoutledgeFalmer, 77-90.

Glaser, B.G. and Strauss, A.L. (1967) The Discovery of Grounded Theory: Strategies for qualitative research. New York: Aldine Publishing Company.

Hahn, C.L. (1994) 'Controversial issues in history instruction'. In Carretero, M. and Voss, J.F. (eds) Cognitive and Instructional Processes in History and the Social Sciences. Hillsdale, NJ: Lawrence Erlbaum Associates, 201-19.

Hand, M. (2008) 'What should we teach as controversial? A defense of the epistemic criterion'. Educational Theory, 58 (2), 213-28.

Hess, D.E. (2009) Controversy in the Classroom: The democratic power of discussion. New York: Routledge.

Hsiao, Y.-M. (2005) 'Taiwanese students' understanding of differences in history textbook accounts'. In Ashby, R., Gordon, P. and Lee, P. (eds) Understanding History: Recent research in history education. London: RoutledgeFalmer, 49-61.

Hynd, C., Holschuh, J.P. and Hubbard, B.P. (2004) 'Thinking like a historian: College students' reading of multiple historical documents'. Journal of Literacy Research, 36 (2), 141-76.

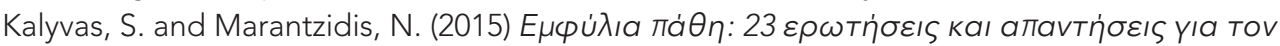

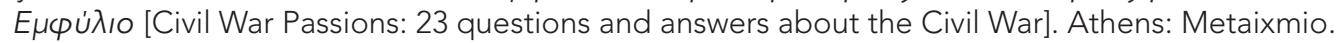

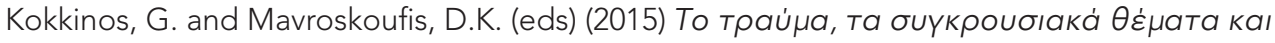

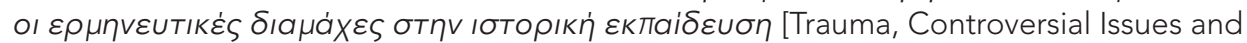
Interpretive Controversies in Historical Education]. Athens: Rodon.

Kokkinos, G., Mavroskoufis, D.K., Gatsotis, P. and Lemonidou, E. (eds) (2010) Ta биүкроибıакá

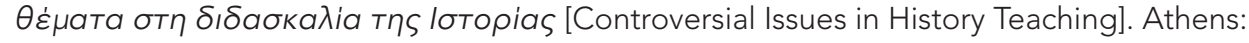
Noogramma.

Krey, A.C. (1933) 'Dealing with controversial topics'. Junior-Senior High School Clearing House, $8(2), 90-3$.

Lee, P. (1998) '"A lot of guess work goes on": Children's understanding of historical accounts'. Teaching History, 92, 29-36. 
Lee, P. (2001) 'History in an information culture: Project CHATA'. International Journal of Historical Learning, Teaching and Research, 1 (2), 75-98.

Lee, P. (2004) 'Understanding history'. In Seixas, P. (ed.) Theorizing Historical Consciousness. Toronto: University of Toronto Press, 129-64.

Lee, P. and Shemilt, D. (2004) '"I just wish we could go back in the past and find out what really happened": Progression in understanding about historical accounts'. Teaching History, 117, 25-31.

Maggioni, L., VanSledright, B. and Alexander, P.A. (2009) 'Walking on the borders: A measure of epistemic cognition in history'. Journal of Experimental Education, 77 (3), 187-213.

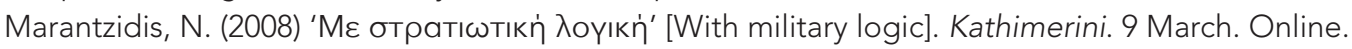
www.kathimerini.gr/315901/article/epikairothta/ellada/h-tragwdia-twn-paidiwn-sta-xronia-toyemfylioy (accessed 25 April 2019).

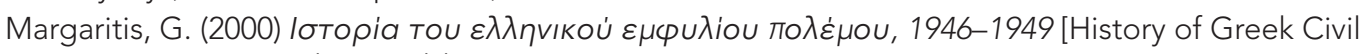
War, 1946-1949]. Athens: Bibliorama.

Martens, M. (2015) 'Understanding the nature of history: Students' tacit epistemology in dealing with conflicting historical narratives'. In Chapman, A. and Wilschut, A. (eds) Joined-Up History: New directions in history education research. Charlotte, NC: Information Age Publishing, 211-30.

McLaughlin, T. (2003) 'Teaching controversial issues in citizenship education'. In Lockyer, A., Crick, B. and Annette, J. (eds) Education for Democratic Citizenship: Issues of theory and practice. Aldershot: Ashgate, 149-60.

Misco, T. (2007) 'Using curriculum deliberation to address controversial issues: Developing Holocaust education curriculum for Latvian schools'. International Journal of Education Policy and Leadership, 2 (8), 1-12.

Park, J. (2008) 'Students' Ideas about Different Representations of the Past: South Korean adolescents interpret historical film'. Unpublished PhD thesis, Institute of Education, University of London.

Queen Frederica of the Hellenes (1971) A Measure of Understanding. London: Macmillan.

Rouet, J.-F., Britt, M.A., Mason, R.A. and Perfetti, C.A. (1996) 'Using multiple sources of evidence to reason about history'. Journal of Educational Psychology, 88 (3), 478-93.

Saye, J.W. and Brush, T. (1999) 'Student engagement with social issues in a multimedia-supported learning environment'. Theory and Research in Social Education, 27 (4), 472-504.

Schweber, S. (2004) Making Sense of the Holocaust: Lessons from classroom practice. New York: Teachers College Press.

Stenhouse, L. (1971) 'The Humanities Curriculum Project: The rationale'. Theory into Practice, 10 (3), 154-62.

Story, M.L. (1952) 'Controversial issues and school administration'. Journal of Educational Sociology, 25 (9), 520-3.

Stradling, R. (2003) Multiperspectivity in History Teaching: A guide for teachers. Strasbourg: Council of Europe.

Stradling, R., Noctor, M. and Baines, B. (1984) Teaching Controversial Issues. London: Edward Arnold.

VanSledright, B. (2002) In Search of America's Past: Learning to read history in elementary school. New York: Teachers College Press.

VanSledright, B.A. and Afflerbach, P. (2005) 'Assessing the status of historical sources: An exploratory study of eight US elementary students reading documents'. In Ashby, R., Gordon, P. and Lee, P. (eds) Understanding History: Recent research in history education. London: RoutledgeFalmer, 1-19.

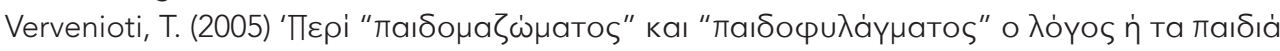

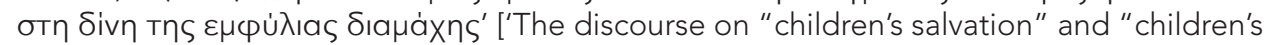
abduction" or children in the maelstrom of the Civil War']. In Boutyra, E., Dalkavoukis, B.,

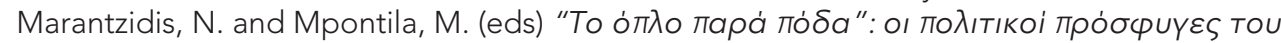

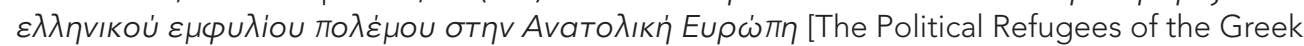
Civil War in Eastern Europe]. Thessaloniki: University of Macedonia Press, 101-23.

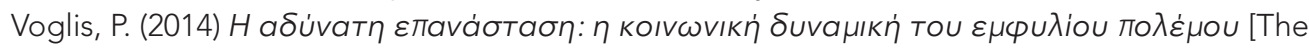
Impossible Revolution: The social dynamics of the Civil War]. Athens: Alexandreia.

Wellington, J.J. (ed.) (1986) Controversial Issues in the Curriculum. Oxford: Basil Blackwell.

Wiley, J. and Voss, J.F. (1996) 'The effects of "playing historian" on learning in history'. Applied Cognitive Psychology, 10 (7), 63-72. 
Wineburg, S.S. (1991a) 'Historical problem solving: A study of the cognitive processes used in the evaluation of documentary and pictorial evidence'. Journal of Educational Psychology, 83 (1), 73-87.

Wineburg, S.S. (1991b) 'On the reading of historical texts: Notes on the breach between school and academy'. American Educational Research Journal, 28 (3), 495-519.

Wineburg, S. and Martin, D. (2009) 'Tampering with history: Adapting primary sources for struggling readers'. Social Education, 73 (5), 212-16. 